\title{
Differences in oxytocin and vasopressin levels in individuals suffering from the autism spectrum disorders vs general population - a systematic review
}

This article was published in the following Dove Press journal:

Neuropsychiatric Disease and Treatment

\author{
Krzysztof M Wilczyński (iD) ${ }^{1,2}$ \\ Ida Zasada ${ }^{1,2}$ \\ Andrzej Siwiec ${ }^{2}$ \\ Małgorzata Janas-Kozik (iD) ${ }^{1,2}$ \\ 'Clinical Ward of Developmental Age \\ Psychiatry and Psychotherapy, \\ Department of Psychiatry and \\ Psychotherapy, Medical University of \\ Silesia, Katowice, Poland; ${ }^{2}$ John Paul Il's \\ Pediatric Centre in Sosnowiec, \\ Sosnowiec, Poland
}

\begin{abstract}
Introduction: Autism spectrum disorder (ASD) is a neurodevelopmental disorder characterized by deficits in social interactions, communication, and the presence of stereotyped, repetitive behaviors. Oxytocin (OXT) and arginine-vasopressin are neuropeptides produced in hypothalamus and they are related to processing emotions and social behavior. In the light of a growing number of scientific reports related to this issue, the two neurohormones started to be linked with the basis of neurodevelopmental disorders, including the ASD. The aim of this study was a systematic review of previous studies regarding the differences in OXT and vasopressin levels in ASD and neurotypical persons.
\end{abstract}

Materials and methods: Literature review focused on publications in the last 10 years located via the MEDLINE/PubMed database as well as the Google Scholar browser. Selection was made by assumptive criteria of inclusion and exclusion.

Results: From the 487 studies qualified to the initial abstract analysis, 12 met the six inclusion criteria and were included in the full-text review.

Conclusion: Currently, available study reports still do not provide unequivocal answers as to the differences in concentrations of those neuropeptides between children with ASD and neurotypical control. Therefore, it is necessary to continue the research taking into account necessity of proper homogenization of study groups, utilization of objective and quantifiable tools for ASD diagnosis and broadening the range of biochemical and molecular factors analyzed.

Keywords: oxytocin, vasopressin, autism spectrum disorder, OXT, AVP, ASD

\section{Introduction}

The Autism spectrum disorder (ASD; also: autism) is a nosological unit present in virtually all populations regardless of their ethnic or socioeconomic backgrounds. ${ }^{1}$ A characteristic feature of the clinical picture of ASD includes symptoms persistent throughout the course of its development in the form of qualitative disorders of social interactions and communication, both in verbal and non-verbal dimensions. ${ }^{2}$ They result from the theory of mind (ToM) deficits, executive functions, and central coherence (CC). The theories of mind and $\mathrm{CC}$ dysfunctions are responsible for social, imagination, and communication deficits, while the executive dysfunctions are responsible for rigidity and repetitive behavior. First symptoms of ASD usually appear in early childhood, they are global in nature and they can be observed in
Correspondence: Krzysztof M Wilczyński Clinical Ward of Developmental Age Psychiatry and Psychotherapy,

Department of Psychiatry and

Psychotherapy, Medical University of

Silesia, Katowice, Poland

Tel +48327207700

Email wilczynskimed@gmail.com 
most cases permanently, regardless of the surrounding or a situation. $^{2,3}$ Prevalence of ASD, despite numerous controversies resulting from differences in classifications of mental disorders, is currently estimated to be around $1 \%$ of the European population. ${ }^{4,5}$ Despite vast resources engaged in the study of ASD, its pathogenesis remains unclear. The best-investigated concepts include the ones which focus on biological hypotheses, concentrating on neuroanatomy, physiology, and genetics of the CNS. Genetic and neurochemical tests are particularly accentuated. Studies on uniovular twins revealed the presence of ASD in both siblings in $70-90 \%$ of the cases. ${ }^{6,7}$ In around $10 \%$ of the cases, the ASD phenotype is secondary to other well-known diseases, such as fragile $\mathrm{X}$ syndrome, tuberous sclerosis complex, or metabolic disorders, e.g. purines, pyrimidines, and folates. ${ }^{3,8}$

Oxytocin (OXT) and arginine-vasopressin (AVP) are two closely related neuropeptides which have arisen much interest in the studies on the etiology of mental disorders. ${ }^{9}$ They are produced in the paraventricular and supraoptic nuclei of the hypothalamus and then they are transported to the posterior pituitary and released into the circulation via which they produce their peripheral effect. ${ }^{10}$ Apart from the above, the oxytocinergic and vasopressinergic neurons, synthesized in the hypothalamus, create numerous projections into other parts of the brain, mainly to the limbic system (e.g. striatum, hippocampus, and amygdala). There, they act in a neuromodulatory manner, for instance for the processes related to processing emotions or social behavior. ${ }^{10-12}$ Despite a close affinity, these two neuropeptides have a contradictory effect in most areas of the brain. For instance, vasopressin is observed to be linked with the feeling of fear and aggression, while OXT seems to reduce these emotions. ${ }^{13}$ In the light of a growing number of scientific reports related to this issue, the two neurohormones started to be linked with the basis of neurodevelopmental disorders, including the ASD. ${ }^{14}$

The aim of this paper is a systematic review of previous studies regarding the differences in OXT and vasopressin levels in ASD and neurotypical persons.

\section{Methodology}

This literature review focused on publications in the last 10 years located via the MEDLINE/PubMed database as well as the Google Scholar browser. The following keywords were used: "autism spectrum disorder", "ASD”, “autism”, “social deficits", “oxytocin”, "argipressin”, “arginine vasopressin”, "OXT", "AVP", "antidiuretic hormone", "wazopresyna", "oksytocyna”, "autyzm”, "poznanie społeczne”. The review included papers in Polish and English published in recognized local and international magazines which were original papers, excluding the studies on animals. The review was performed by each author independently in three stages, based on the following six inclusion criteria:

1. Papers published between January 2008 and August 2018;

2. Papers published in the English or Polish language.

3. Papers issued as magazine articles (e.g. book chapters were excluded)

4. Papers which directly focused on the comparison of OXT and vasopressin levels in groups of ASD patients vs neurotypical patients.

5. Papers which clearly and comprehensively presented methodology (e.g. inclusion and exclusion criteria), demographic data about participants as well as methodology of confirming or excluding the AD diagnosis.

6. Papers which applied a good methodology (e.g. reliable scientific tools validated for a target population, clearly defined scientific hypotheses, a satisfactory description of applied statistical methods).

The first stage of the review covered the search for publications as well as the analysis of their compatibility with the subject of the review on the basis of the title of the paper. During the second stage, the abstract was analyzed in terms of the inclusion criteria. The studies which were qualified for further analysis by each author were compared and, once duplicates were eliminated, they underwent a preliminary full-text analysis aimed at the evaluation of their compatibility with the assumed inclusion criteria. Furthermore, the analysis of bibliography of the included papers was carried out. Finally, 12 papers were included in the review. They underwent a qualitative assessment with the modified Newcastle-Ottawa Quality Assessment Scale for Case Control Studies (NOQAS) - a point was awarded per each parameter $(0 ; 1 / 2$ or 1$)$ instead of stars.

\section{Results}

Initially, based on the previously assumed keywords, 487 publications were identified, out of which, after the first stage, 233-245 papers were included for further review, depending on the author. In the second stage, 199-204 papers were excluded, as they were found to be in conflict with the inclusion criteria. Upon comparing the results of the review among the authors and removing duplicates, the total number of 29 publications were qualified to the third stage, out of which 10 were included in the final analysis. Additional two 
papers were identified in the course of bibliographical analysis (Table 1). A detailed selection procedure is presented in Figure 1.

\section{Discussion of the results}

The conducted literature review revealed a significant heterogeneity of the results available in the literature on the subject which are frequently contradictory and make it impossible to draw unequivocal conclusions. This may result, among others, from the heterogeneous methodologies, demographic differences among groups or a generally low quality of publications. The mean NOQAS score was 6.3 per maximum 9, which is an average result. What is more, only 4 out of 12 analyzed studies applied recognized diagnostic tools in order to diagnose ASD, which may have a considerable impact on the homogeneity of the clinical group, and, consequently, credibility of results.

Although the studies of Taurines et al, of $2014^{12}$ and Althaus et al, of $2016^{15}$ did not reveal any statistically

Table I Review of publications finally included in the full-text analysis

\begin{tabular}{|c|c|c|c|c|c|c|c|c|}
\hline Publication & $\mathbf{n}$ & $\begin{array}{l}\text { n studied } \\
\text { group } \\
\text { (girls) }\end{array}$ & $\begin{array}{l}\text { n g. } \\
\text { control } \\
\text { (girls) }\end{array}$ & Diagnosis & $\begin{array}{l}\text { Participants' } \\
\text { age M (SD) }\end{array}$ & Conclusion & $\begin{array}{l}\text { Materials } \\
\text { and } \\
\text { methods }\end{array}$ & $\begin{array}{l}\text { Publication's } \\
\text { evaluation }^{\text {d }}\end{array}$ \\
\hline $\begin{array}{l}\text { Taurines } \\
\text { et al, } 2014^{12}\end{array}$ & 36 & 19 & 17 & $\begin{array}{l}\text { DSM; ADI-R; } \\
\text { ADOS }\end{array}$ & $10.7(3.8)$ years & $\begin{array}{l}\text { OXT in the ASD group } \\
(p=0.132)^{b}\end{array}$ & $\begin{array}{l}\text { Plasma } \\
\text { RIA }\end{array}$ & 8 \\
\hline $\begin{array}{l}\text { Modahl et al, } \\
1998^{31}\end{array}$ & 59 & 29 & 30 & DSM & $8.08(1.6)$ years & OXT in the ASD group ${ }^{c}$ & $\begin{array}{l}\text { Plasma } \\
\text { RIA }\end{array}$ & 6.5 \\
\hline $\begin{array}{l}\text { Alabdali } \\
\text { et al, } 2014^{32}\end{array}$ & 80 & 50 & 30 & DSM & $7.0(2.34)$ years & OXT in the ASD group ${ }^{c}$ & $\begin{array}{l}\text { Plasma } \\
\text { ELISA }\end{array}$ & 6 \\
\hline $\begin{array}{l}\text { Green et al, } \\
2001^{33}\end{array}$ & 59 & 28 & 31 & DSM & $\begin{array}{l}8.08(1.6) \text { years } \\
5.8-11.58 \\
\text { years }\end{array}$ & OXT in the ASD group ${ }^{c}$ & $\begin{array}{l}\text { Plasma } \\
\text { RIA }\end{array}$ & 5.5 \\
\hline $\begin{array}{l}\text { Al-Ayadhi } \\
2005^{19}\end{array}$ & 154 & $77(6)$ & $77(6)$ & DSM & $3.5-14$ years & $\begin{array}{l}\text { OXT in the ASD group } \\
\text { AVP in the ASD group }\end{array}$ & $\begin{array}{l}\text { Plasma } \\
\text { ELISA }\end{array}$ & 4 \\
\hline $\begin{array}{l}\text { Abdulamir } \\
\text { et al, } 2016^{34}\end{array}$ & 86 & 60 & 26 & DSM & $\begin{array}{l}7.28(2.89) \\
\text { years }\end{array}$ & OXT in the ASD group ${ }^{c}$ & $\begin{array}{l}\text { Plasma } \\
\text { ELISA }\end{array}$ & 6 \\
\hline $\begin{array}{l}\text { Althaus et al, } \\
2016^{15}\end{array}$ & 61 & 31 & 30 & DSM & $\begin{array}{l}22.67(422) \\
\text { years } \\
18-34 \text { years }\end{array}$ & $\begin{array}{l}\text { OXT in the ASD group } \\
(p=0.05)^{\mathrm{b}}\end{array}$ & $\begin{array}{l}\text { Plasma } \\
\text { RIA }\end{array}$ & 7.5 \\
\hline $\begin{array}{l}\text { Boso et al, } \\
2007^{20}\end{array}$ & 39 & $18(2)$ & $21(3)$ & DSM & $\begin{array}{l}27.5(7.2) \text { years } \\
15-42 \text { years }\end{array}$ & AVP in the ASD group ${ }^{a}$ & $\begin{array}{l}\text { Plasma } \\
\text { ELISA }\end{array}$ & 5 \\
\hline $\begin{array}{l}\text { Zhang et al, } \\
2016^{17}\end{array}$ & 169 & $84(13)$ & $85(14)$ & DSM & $\begin{array}{l}3.95(1.26) \\
\text { years } \\
2-7 \text { years }\end{array}$ & $\begin{array}{l}\text { OXT in the ASD group } \\
\text { AVP in the ASD group } \\
(p=0.477)^{b}\end{array}$ & $\begin{array}{l}\text { Plasma } \\
\text { ELISA }\end{array}$ & 7.5 \\
\hline $\begin{array}{l}\text { Carson et al, } \\
2015^{21}\end{array}$ & 112 & $57(9)$ & $55(19)$ & $\begin{array}{l}\text { DSM; ADI-R; } \\
\text { ADOS }\end{array}$ & $\begin{array}{l}8.58(0.45) \\
\text { years }\end{array}$ & $\begin{array}{l}\text { No differences between } \\
\text { the groups (AVP; } p>0.05 \text { ) }\end{array}$ & $\begin{array}{l}\text { Plasma } \\
\text { ELISA }\end{array}$ & 6 \\
\hline $\begin{array}{l}\text { Miller et al, } \\
2013^{11}\end{array}$ & 75 & $40(19)$ & $35(16)$ & $\begin{array}{l}\text { DSM; ADI-R; } \\
\text { ADOS }\end{array}$ & $8-18$ years & $\begin{array}{l}\text { No differences between } \\
\text { the groups (OXT; } p>0.05 \text { ) } \\
\text { No differences between } \\
\text { the groups (AVP; } p>0.05 \text { ) }\end{array}$ & $\begin{array}{l}\text { Plasma } \\
\text { ELISA }\end{array}$ & 7.5 \\
\hline $\begin{array}{l}\text { Jacobson } \\
\text { et al, } 2014^{16}\end{array}$ & 78 & $37(12)$ & $41(17)$ & $\begin{array}{l}\text { DSM; ADI-R; } \\
\text { ADOS }\end{array}$ & $\begin{array}{l}4.73(0.61) \\
\text { years }\end{array}$ & OXT in the ASD group ${ }^{a}$ & $\begin{array}{l}\text { Plasma } \\
\text { ELISA }\end{array}$ & 8 \\
\hline
\end{tabular}

Notes: ancreased level; bincreased level but statistically insignificant result; ' Decreased level. ${ }^{\mathrm{d} A c c o r d i n g}$ to the Newcastle-Ottawa Quality Assessment Scale for Case Control Studies - max 9 pkt.

Abbreviations: DSM, diagnostic and statistical manual of mental disorders IV-TR; ADI-R, autism diagnostic interview - reviewed; ADOS, autism diagnostic and observation schedule; OXT, oxytocin; ASD, autism spectrum disorde; ELISA, enzyme-linked immunorbent assay; AVP, arginine-vasopressin. 


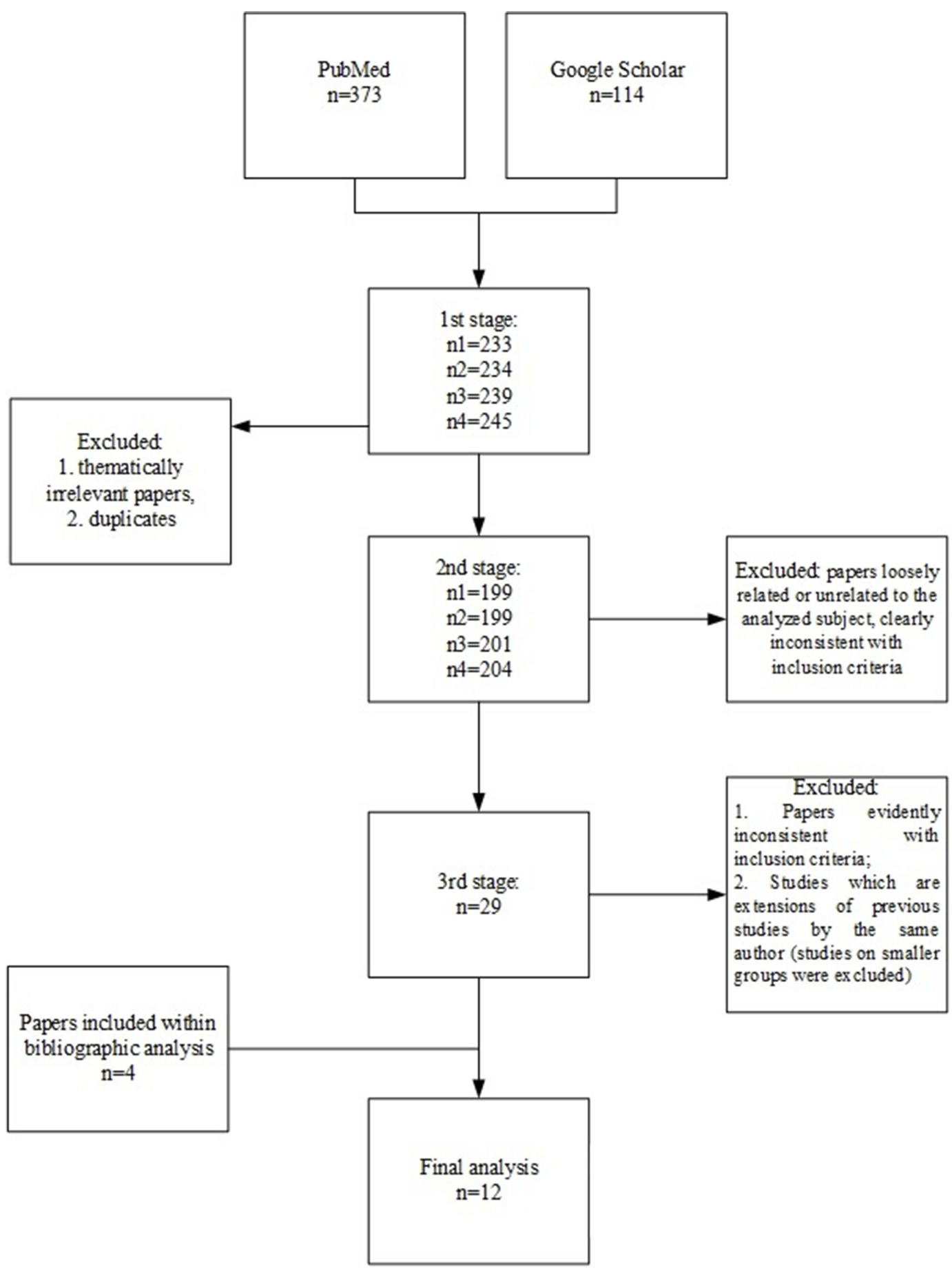

Figure I The qualification procedure of papers for the review.

significant difference between groups, they pointed to an increased OXT concentration in the ASD children. Jacobson et al, ${ }^{16}$ in 2014 drew similar conclusions and observed a statistically significant difference between the groups.

Interestingly, some of the analyzed papers seem to suggest a contrary hypothesis, i.e. lower OXT levels in the group of ASD children. Results in line with this hypothesis were presented for example by Zhang et al, in $2016 ;{ }^{17}$ however, once the studied group was divided into boys and girls the observed difference was only observed in boys $(p=0.028)$ and it disappeared among the girls $(p=0.42)$. In the study of Miller et al, of 2013, the authors did not reveal any significant differences in OXT levels in ASD children vs neurotypical 
individuals, ${ }^{11}$ nevertheless they described a statistically significant effect of the sex on OXT level, where in girls the OXT concentration were higher than in boys, regardless of diagnosis $(\mathrm{F}(1.68)=4.53 ; p=0.037)$.

Despite the lack of unequivocal bases to draw conclusions regarding the differences in OXT levels between the ASD and control groups, papers have been published which analyze the use of OXT to reduce symptoms in this group of patients. In the meta-analysis of the studies devoted to the application of this type of treatment carried out by Preti et al, in 2014, which included seven randomized controlled trials it was observed that there is a slight improvement only in terms of single symptoms which persisted up to 6 weeks only in the case of one study. So, despite initial enthusiasm regarding optimistic results on healthy individuals and in small groups of patients, consecutive outcomes cooled down the scientists' aspirations. ${ }^{18}$

Literature regarding the levels of AVP in the ASD children vs neurotypical groups is extremely poor and the available studies present contradictory outcomes. One of the first papers was published by Al-Ayadhi ${ }^{19}$ in 2005 and it observed a significantly decreased AVP level in the group of ASD children $(0.81 \pm 0.03 \mathrm{pg} / \mathrm{mL})$ as compared to the control $(1.01 \pm 0.02 \mathrm{pg} / \mathrm{mL} ; p<0.05)$. In the 2007 report by Boso et al, ${ }^{20}$ a reverse effect was described, where a higher AVP concentration was observed in the ASD group $(1.47 \pm 0.4 \mathrm{pg} / \mathrm{mL})$ as compared to the control $(1.22 \pm 0.26 \mathrm{pg} / \mathrm{mL} ; p=0.02)$. On the other hand, the lack of statistically significant differences between the groups was observed in three following studies carried out by Miller et al, ${ }^{11}$ in 2013, Carson et al, in 2015, ${ }^{21}$ and Zhang et al, in $2016 .{ }^{17}$ However, in the study by Carson et al, apart from a direct comparison of groups, the AVP levels were also correlated with the results obtained in the test of the ToM. The researchers revealed that in the group of ASD individuals the ToM result was much more correlated with the AVP level than in the neurotypical groups $(\mathrm{F}(1144)$ $=5.83 ; p=0.017)$. In the meantime, Miller et al, also for AVP revealed a statistically significant impact of the sex on the neuropeptide concentration, regardless of a diagnosis - this time higher levels were observed in boys $(p=0,043)$. What is more, for AVP Miller et al, showed also interesting results of the study of correlations with the social responsiveness scale and repetitive behavior scale. For girls, statistically significant correlations were only obtained with the OXT level, while in boys with AVP.

\section{Discussion and conclusions}

Despite a considerable degree of heterogeneity and even contradictions of the results of studies on differences in neuropeptide levels in the ASD patients vs neurotypical individuals, what one should keep in mind is the arguments for the existence of such a difference which come from, among others, neuroimaging. In the study by Kurth et al, of $2011^{22}$ on the group of 104 children (52 with confirmed ASD and 52 controls), by means of magnetic resonance imaging, a significant reduction of the gray matter volume of the hypothalamus in the region of the paraventricular and supraoptic nuclei was observed in the ASD children. According to the authors, this type of lesion may result from atrophy of neurons located in these nuclei which are responsible for vasopressin and OXT secretion. Further results were also presented in the study of Shou et al, ${ }^{23}$ of 2017 , in which significant changes in the volume and the number of connections between the structures with vasopressinergic neurons were observed in the group of children with ASD. On the other hand, studies on other nosological entities revealed data that suggests the participation of these neuropeptides in such disorders as ADHD or obsessive-compulsive disorder which are often accompanying the ASDs. ${ }^{13,17}$ This can also be an argument for the participation of these neuropeptides in the development of ASD. What is then the source of the observed contradiction of the results available in the literature?

First of all, the issues related to the applied methodologies should be taken into consideration. As can be seen in Table 1, most papers published in this thematic field are based on a purely criterial diagnosis. Although this method is widely accepted, it is also connected with a greater risk of error while diagnosing than validated diagnostic protocols, such as, for instance, Autism Diagnostic and Observation Schedule. Furthermore, criterial diagnosing imposes a subjective assessment of the severity of various domains of symptoms within the ASD in a given individual, which, again, may lead to a great heterogeneity of clinical pictures in the control group. Secondly, although most of the authors provide at least some details on procedures and methods used, usually those are vague and does not cover the technical issues. In majority of papers $(n=8)$ included into this review authors utilized enzyme-linked immunosorbent assay for evaluation of OXT and AVP concentrations, and four used radioimmunoassay (Table 1). The lack of methodological standards are further factor that might influence the credibility of juxtaposition of data available in the literature. 
In the analyzed studies, the age differences in the studied groups are also evident and the age lowest mean was 3.95 years in the study of Zhang et al, ${ }^{17}$ and the highest -22.67 for OXT in the study of Althaus et al, ${ }^{15}$ and 27.5 years for vasopressin in the study of Boso et al, ${ }^{20}$ respectively. The heterogeneity of the papers in terms of age may prove significant, which is suggested by e.g. Francis et al, in the paper of $2015,{ }^{24}$ in which authors postulate the existence of a difference in OXT concentrations in children with ASD as compared to the general population at the same time observing that these differences disappear with age and they are not observed in adults. In the same paper, Francis et al, point to another interesting issue, discussing the OXT precursor. According to the authors, its level suggests a positive correlation with the severity of the ASD symptoms, and is increased in this group of patients, which was also confirmed by other authors $^{25}$ and which should be taken into account in the future studies on oxytoci- and vasopressinogenic systems.

Differentiating between males and females is also of special interest for researchers in the field of ASD as there is a clear difference in the clinical picture and the prevalence between sexes. ${ }^{26}$ According to the meta-analysis of 2017 by Loomes et al, ${ }^{27}$ ASD is diagnosed three times more often in boys than in girls and according to the authors it results mainly from the differences in the clinical picture which are the reason why girls who fulfill the ASD diagnostic criteria often do not receive such a diagnosis in the end. This type of differences may reflect a certain disparity in the ASD pathophysiology between the sexes, and, consequently, may significantly affect the obtained study results. This seems evident especially for OXT and vasopressin, in case of which it has for years been postulated to introduce sexual dimorphism in functions related to social cognition and modulation of brain function. ${ }^{25}$ This hypothesis is supported by studies carried out by inter allia Aita et al, ${ }^{28}$ Zhang et al, ${ }^{17}$ and Miller et al, ${ }^{11}$ and it is well recognized. This issue points to the necessity of group homogenization in terms of the sex in the future studies, and also of deepening the analyses in this field, which may bring interesting conclusions in terms of different pathophysiology of ASD in boys and girls.

In the case of studies focusing on the dysfunctions of the oxytocinergic and vasopressinergic systems in the course of ASF it should be remembered that their deficits may not be linked with the complete clinical picture, but with its part - social cognition dysfunctions in particular. And if a degree of severity of this type of symptoms is not controlled in the control group, this may lead to serious errors while interpreting the results. This type of hypothesis was put forward, for instance, by Harony et al, in $2010,{ }^{29}$ who observed that OXT and vasopressin have a contradictory effect, increasing and decreasing the function, respectively, on the hypothalamus-pituitary-adrenal axis, and consequently, on the level of cortisol in plasma and stress intensification, but also on the function of the amygdala which is a key element of the anxiety reaction. And according to the authors, at the increased level of vasopressin and decreased level of OXT, this leads to the social anxiety and development or intensification of social cognition dysfunctions in the course of ASD. However, there are a few studies which contradict this hypothesis, such as Miller et al, of 2013, ${ }^{11}$ who observed a positive correlation between anxiety severity and OXT level in girls with ASD; Zhang et al, of $2016^{17}$ in which vasopressin level correlated with the number of stereotypical behaviors; or Carson et al, $2015^{21}$ in which the AVP level correlated with the result of the ToM test.

The study of Oztan et al, of $2018^{30}$ revealed that testing the levels of AXT and AVP in connection with measurements of the gene expression levels for the OXT and vasopressin receptor correctly differentiated neurotypical and ASD individuals in $84 \%$ of the cases. Such results give hope for the development of specific and sensitive methods of laboratory diagnostics of ASD early in life. However, currently available study reports still do not provide clear answers as to the possible application of neuropeptides as this kind of tool. Therefore, it is necessary to continue the research which takes into consideration a few significant aspects.

First of all, it is crucial to maintain the homogeneity of the groups, in terms of the sex and age in particular, and also to choose controls appropriate in this respect. Secondly, it is extremely important to apply maximum objective and quantifiable measurement tools in the studies to facilitate the assessment of the severity of various domains of ASD symptoms, especially in terms of social cognition. Furthermore, unification of utilized assays as well as more detailed descriptions of technical issues is crucial to assure comparability of published data. Subsequently, it would also be advisable to include in the analysis not only the neuropeptides themselves, but also cortisol concentration together with the test of social anxiety levels among participants. Finally, the studies should cover in a comprehensive manner not only the measurements of AVP and OXT but also the level of expression of 
their receptors, OXT precursor and, if possible, an analysis of genes for these proteins in terms of polymorphisms.

\section{Disclosure}

The authors report no conflicts of interest in this work.

\section{References}

1. Fombonne E. Prevalence of childhood disintegrative disorder. Autism. 2002;6(2):149-157. doi:10.1177/1362361302006002002

2. American Psychiatric Association: Statistical Manual of Mental Disorders. 5th ed. Washington, DC: American Psychiatric Association; 2013

3. Yates K, Le CA, Szczęsny E (tłumaczenie).Diagnostyka autyzmu. Paediatr Child Heal.2009;19:55-59. doi:10.1016/j.paed.2008.10.010

4. Duchan E, Patel DR. Epidemiology of autism spectrum disorders. Pediatr Clin North Am. 2012;59(1):27-43. doi:10.1016/j.pcl.2011. 10.003

5. Rybakowski F, Białek A, Chojnicka I, et al. Zaburzenia ze spektrum autyzmu - epidemiologia, objawy, współzachorowalno:̈ć i rozpoznawanie. Psychiatr Pol. 2014;48(4):653-665.

6. Zhang R, Zhang HF, Han JS, Han SP. Genes related to oxytocin and arginine-vasopressin pathways: associations with autism spectrum disorders. Neurosci Bull. 2017;33(2):238-246. doi:10.1007/s12264017-0120-7

7. Hovey D, Zettergren A, Jonsson L, et al. Associations between oxytocin-related genes and autistic-like traits. Soc Neurosci. 2014;9 (4):378-386. doi:10.1080/17470919.2014.897995

8. Gillberg C, Billstedt E. Autism and asperger syndrome: coexistence with other clinical disorders. Acta Psychiatr Scand. 2000;102 (5):321-330. doi:10.1034/j.1600-0447.2000.102005321.x

9. Carter CS. Oxytocin pathways and the evolution of human behavior. Annu Rev Psychol. 2014;65(1):17-39. doi:10.1146/annurev-psych010213-115110

10. Wigton R, Radua J, Allen P, et al. Neurophysiological effects of acute oxytocin administration: systematic review and meta-analysis of placebo-controlled imaging studies. J Psychiatry Neurosci. 2015;40 (1):1-22. doi:10.1503/jpn.130289

11. Miller M, Bales KL, Taylor SL, et al. Oxytocin and vasopressin in children and adolescents with autism spectrum disorders: sex differences and associations with symptoms. Autism Res. 2013;6(2):91102. doi:10.1002/aur.1270

12. Taurines R, Schwenck C, Lyttwin B, et al. Oxytocin plasma concentrations in children and adolescents with autism spectrum disorder: correlation with autistic symptomatology. Atten Deficit Hyperact Disord. 2014;6(3):231-239. doi:10.1007/s12402-014-0145-y

13. Wójciak P, Remlinger-Molenda A, Rybakowski J. Rolaoksytocyny i wazopresyny w czynności ośrodkowego ułkadu nerwowego i w zaburzeniach psychicznych. Psychiatr Pol. 2012;46(6):1043-1052.

14. Schmeisser MJ, Boeckers TM, editors. Translational Anatomy and Cell Biology of Autism Spectrum Disorder. New York: Springer International Publishing; 2017.

15. Althaus M, Groen Y, Wijers AA, et al. Do blood plasma levels of oxytocin moderate the effect of nasally administered oxytocin on social orienting in high-functioning male adults with autism spectrum disorder? Psychopharmacology (Berl). 2016;233:2737-2751. doi:10.1007/ s00213-016-4339-1

16. Jacobson JD, Ellerbeck KA, Kelly KA, et al. Evidence for alterations in stimulatory $\mathrm{G}$ proteins and oxytocin levels in children with autism. Psychoneuroendocrinology. 2014;40(1):159-169. doi:10.1016/j.psyn euen.2013.11.014
17. Zhang HF, Dai YC, Wu J, et al. Plasma oxytocin and argininevasopressin levels in children with autism spectrum disorder in china: associations with symptoms. Neurosci Bull. 2016;32(5):423432. doi: $10.1007 / \mathrm{s} 12264-016-0046-5$

18. Preti A, Melis M, Siddi S, Vellante M, Doneddu G, Fadda R. Oxytocin and Autism: A Systematic Review of Randomized Controlled Trials. J Child Adolesc Psychopharmacol. 2014;24 (2):54-68. doi:10.1089/cap.2013.004

19. Al-Ayadhi LY. Altered oxytocin and vasopressin levels in autistic children in Central Saudi Arabia. Neurosciences. 2005;10(1):47-50.

20. Boso M, Emanuele E, Politi P, et al. Reduced plasma apelin levels in patients with autistic spectrum disorder. Arch Med Res. 2007;38 (1):70-74. doi:10.1016/j.arcmed.2006.08.003

21. Carson DS, Garner JP, Hyde SA, et al. Arginine vasopressin is a blood-based biomarker of social functioning in children with autism. PLoS ONE. 2015:1-14. doi:10.1371/journal.pone.0132224

22. Kurth F, Narr KL, Woods RP, et al. Diminished gray matter within the hypothalamus in autism disorder: a potential link to hormonal effects? Biol Psychiatry. 2011;70(3):278-282. doi:10.1016/j.biopsych.2011. 03.026

23. Shou X, Xu X, Liu XZY. A volumetric and functional connectivity MRI study of brain arginine-vasopressin pathways in autistic children. Neurosci Bull. 2017;33(2):130-142. doi:10.1007/s12264-0170109-2

24. Francis SM, Sagarb A, Levin-Decaninia T, Liuc W, Carterd CS, Jacob S. Oxytocin and vasopressin systems in genetic syndromes and neurodevelopmental disorders. Brain Research. 2015;199-218. doi:10.1016/j.brainres.2014.01.021.Oxytocin

25. Carter CS. Sex differences in oxytocin and vasopressin: implications for autism spectrum disorders? Behav Brain Res. 2007;176(1):170186. doi:10.1016/j.bbr.2006.08.025

26. Rynkiewicz A, Janas-Kozik M, Słopień A. Girls and women with autism. Psychiatr Pol. 2018;2:1-16. doi:10.12740/PP/OnlineFirst/ 95098

27. Loomes R, Hull L, Mandy WPL. What is the male-to-female ratio in autism spectrum disorder? A systematic review and meta-analysis. $J$ Am Acad Child Adolesc Psychiatry. 2017;56(6):466-474. doi:10.1016/j.jaac.2017.03.013

28. Aita C, Mizoguchi Y, Yamamoto M, et al. Oxytocin levels and sex differences in autism spectrum disorder with severe intellectual disabilities. Psychiatry Res. 2019;273:67-74. doi:10.1016/j.psychres. 2018.12.139

29. Harony H, Wagner S. The contribution of oxytocin and vasopressin to mammalian social behavior: potential role in. Neurosignals. 2010;82-97. doi:10.1159/000321035

30. Oztan O, Jackson LP, Libove RA, et al. Biomarker discovery for disease status and symptom severity in children with autism. Psychoneuroendocrinology. 2018;89:39-45. doi:10.1016/j.psyneuen. 2017.12.022

31. Modahl C, Green LA, Fein D, et al. Plasma oxytocin levels in autistic children. Biol Psychiatry. 1998;43(4):270-277. doi:10.1016/S00063223(97)00439-3

32. Alabdali A, Al-ayadhi L, El-ansary A. Association of social and cognitive impairment and biomarkers in autism spectrum disorders. $J$ Neuroinflammation. 2014;11:4. doi:10.1186/1742-2094-11-4

33. Green L, Fein D, Modahl C, Feinstein C, Waterhouse L, Morris M. Oxytocin and autistic disorder: alterations in peptide forms. Biological Psychiatry. 2001;3223(1985):609-613.

34. Abdulamir HA, Abdul-Rasheed OF, Abdulghani EA. Low oxytocin and melatonin levels and their possible role in the diagnosis and prognosis in Iraqi autistic children. Saudi Med J. 2016;37(1):29-36. doi:10.15537/smj.2016.1.13183 


\section{Publish your work in this journal}

Neuropsychiatric Disease and Treatment is an international, peerreviewed journal of clinical therapeutics and pharmacology focusing on concise rapid reporting of clinical or pre-clinical studies on a range of neuropsychiatric and neurological disorders. This journal is indexed on PubMed Central, the 'PsycINFO' database and CAS, and is the official journal of The International Neuropsychiatric Association (INA). The manuscript management system is completely online and includes a very quick and fair peer-review system, which is all easy to use. Visit http://www.dovepress.com/testimonials.php to read real quotes from published authors. 